\title{
Effects of Ixeris dentata water extract and caffeic acid on allergic inflammation in vivo and in vitro
}

Yong-Deok Jeon ${ }^{1,2+}$, Ji-Ye Kee ${ }^{1 \dagger}$, Dae-Seung Kim ${ }^{1}$, Yo-Han Han ${ }^{1}$, Sung-Hoon Kim³ ${ }^{3}$ Su-Jin Kim ${ }^{4}$, Jae-Young $\mathrm{Um}^{3^{*}}$ and Seung-Heon Hong ${ }^{1 *}$

\begin{abstract}
Background: Ixeris dentata Nakai has been used for the treatment of mithridatism, calculous, indigestion, pneumonia, hepatitis, and tumors in Korea, China, and Japan. However, the effect of a water extract of Ixeris dentata (ID) and its molecular mechanism on allergic inflammation has not been elucidated. In this study, we attempted to evaluate the effects of ID and its major compound caffeic acid on allergic inflammation in vivo and in vitro.

Methods: ID was applied to 2, 4-dinitrofluorobenzene (DNFB)-induced atopic dermatitis (AD)-like skin lesion mice and immune cell infiltration, cytokine production, and the activation of mitogen-activated protein kinases (MAPKs) were investigated. Moreover, the effect of ID on compound 48/80-induced anaphylactic shock was investigated in a mouse model. The human keratinocyte cell line (HaCaT cells) and human mast cells (HMC-1) were treated with ID or caffeic acid to investigate the effects on the production of chemokines and proinflammatory cytokines and on the activation of MAPKs.

Results: ID inhibited the serum levels of IgE and interleukin (IL)-1 $\beta$ in DNFB-induced AD-like skin lesion mouse models and suppressed anaphylactic shock in the mouse models. ID and caffeic acid inhibited the production of chemokines and adhesion molecules in $\mathrm{HaCaT}$ cells. In addition, ID reduced the release of tumor necrosis factor-a and IL-8 via the inhibition of MAPKs phosphorylation in HMC-1 cells.
\end{abstract}

Conclusions: These results suggest that ID is a potential therapeutic agent for allergic inflammatory diseases, including dermatitis.

Key words: Ixeris dentata Nakai, Caffeic acid, Allergic inflammation, Keratinocytes, Mast cells, Mitogen-activated protein kinases

\section{Background}

Atopic dermatitis (AD), also known as atopic eczema, is a common, chronic and allergic inflammatory skin disease [1]. The worldwide prevalence rate of AD is nearly $10-20 \%$ in children and $1-3 \%$ in adults. Genetic and environmental factors are important causes in many $\mathrm{AD}$ patients [2]. Immune system disorders cause $\mathrm{AD}$, which is related to several types of cells ( $\mathrm{T}$ lymphocytes, macrophages, mast

\footnotetext{
* Correspondence: jyum@khu.ac.kr; jooklim@wku.ac.kr

${ }^{\dagger}$ Equal contributors

${ }^{3}$ College of Korean Medicine, Institute of Korean Medicine, Kyung Hee University, 26 Kyungheedae-ro, Dongdaemun-gu, Seoul, Republic of Korea 'Department of Oriental Pharmacy, College of Pharmacy, Wonkwang-Oriental Medicines Research Institute, Wonkwang University, Jeonbuk 570-749, Republic of Korea

Full list of author information is available at the end of the article
}

cells, and keratinocytes), specifically $\mathrm{T}$ helper (Th) cell dysfunction and IgE production $[3,4]$.

Ixeris dentata Nakai (Compositae) has been used for the treatment of mithridatism, calculous, indigestion, pneumonia, hepatitis, and tumors in Korea, China, and Japan [5]. It has been reported that Ixeris dentata has neuroprotective effects [6], anti-diabetic effects [7], protection effects against colitis and skin inflammation $[8,9]$, and antiallergic effects $[10,11]$. In this study, the effect of the Ixeris dentata water extract (ID) on allergic inflammatory reactions via MAPKs signaling was investigated in human keratinocytes and human mast cells and was also assessed in vivo.

Keratinocytes, which are the main type of epidermal cells, play a key role in the pathogenesis of $\mathrm{AD}$ [12]. Epidermal keratinocytes release various inflammatory mediators, such

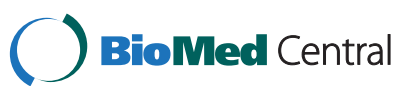


as chemokines and adhesion molecules by tumor necrosis factor (TNF)- $\alpha$ and interferon (IFN) $-\gamma$ stimulations [13, $14]$; these factors are involved in the development of inflammatory skin diseases, including AD. Thymus and activation-regulated chemokine (TARC or CCL17) as well as macrophage-derived chemokine (MDC or CCL22), which are Th2 chemokines, mediate the migration of lymphocytes to inflammatory sites and aggravate AD [15]. Additionally, the levels of TARC and MDC are elevated in serum and skin lesions of $\mathrm{AD}$ patients $[16,17]$.

Mast cells are hematopoietic cells that originate from progenitor cells in the bone marrow. They are considered as key effector cells in IgE-mediated immediate hypersensitivity and allergic disorders [18]. In response to various stimuli, mast cells secrete a variety of bioactive substances, such as histamine and several proinflammatory cytokines, including interleukin (IL)-8 and TNF. These mediators contribute to inflammation through the recruitment and activation of immune cells [19]. Mast cells are increased in a majority of $\mathrm{AD}$ patients and are believed to be involved in the pathogenesis of AD [20].

Nuclear factor-kappaB (NF-kB) plays a pivotal role in the regulation of immune and inflammatory responses through the expression of cytokine, chemokine, and adhesion molecules. When I $\mathrm{K} B$ proteins are phosphorylated and degraded after stimulation, NF- $\mathrm{kB}$ is translocated into the nucleus and initiates the transcription of genes that are crucial in the development of inflammatory diseases. Therefore, the activation of NF- $\mathrm{kB}$ is important in the progression of allergic inflammation [21-23].

Mitogen-activated protein kinases (MAPKs) signaling pathway controls a vast array of physiological processes. In multicellular organisms, there are three well-characterized subfamilies of MAPKs. These MAPKs include the extracellular signal-regulated kinases (ERKs); the c-jun $\mathrm{N}$-terminal kinases (JNKs); and the p38 MAPKs [24]. It has shown to be important in the proliferation, activation, degranulation, and migration of various immune cells. The activation of MAPKs is associated with the allergic inflammatory response via the translocation of NF- $\mathrm{kB}$, which causes the production of proinflammatory cytokines and chemokines [25-27]. Synthetically, the inhibition of NF- $\mathrm{KB}$ and MAPKs activation has been suggested as an anti-inflammatory strategy in allergic inflammation.

In this study, we evaluated the effect of ID on DNFBinduced $\mathrm{AD}$-like skin lesion and anaphylactic shock in mouse models. We also examined the inhibitory effects of ID and its major compound, caffeic acid, on the productions of TNF- $\alpha / \mathrm{IFN}-\gamma$-induced chemokines and adhesion molecules in the human keratinocyte $\mathrm{HaCaT}$ cell line. Moreover, the effects of ID and caffeic acid on phorbol 12myristate 13-acetate (PMA)/calcium ionophore A23187 (A23287)-induced proinflammatory cytokines productions as well as its mechanisms were investigated in human mast cells (HMC-1).

\section{Methods}

\section{Antibodies and reagents}

2, 4-dinitrofluorobenzene (DNFB), compound 48/80, 3-(4, 5-Dimethylthiazol-2-yl)-2, 5-diphenyltetrazolium bromide (MTT), PMA, and A23187 were purchased from SigmaAldrich Chemical Co. (St. Louis, MO, USA). Avidin peroxidase (AP), fetal bovine serum (FBS), Roswell Park Memorial Institute (RPMI) 1640, and Iscove's Modified Dulbecco's Medium (IMDM) were purchased from Gibco BRL (Grand Island, NY, USA). Anti-human TNF- $\alpha /$ IL-6/IL-8, recombinant TNF- $\alpha / \mathrm{IL}-6 / \mathrm{IL}-8$, biotinylated TNF- $\alpha / \mathrm{IL}-$ 6/IL-8, anti-mouse IgE/IL-1 $\beta$, recombinant IgE, IL- $1 \beta$, biotinylated IgE, and IL-1 $\beta$ were purchased from BD Pharmingen (San Diego, CA, USA). Anti-phospho p38 antibody was purchased from Cell Signaling Technology, Inc. (Danvers, MA, USA). Anti-phospho ERK, JNK, IкB $\alpha$, anti-p38, JNK, NF- $\kappa$ B, histone, and GAPDH antibodies were purchased from Santa Cruz Biotechnology, Inc. (Santa Cruz, CA, USA). Anti-ERK, and $\alpha-$ tubulin antibodies were purchased from Bioworld Technology (Minneapolis, MN, USA).

\section{Animals}

$\mathrm{BALB} / \mathrm{c}$ mice (5 weeks, male, 19-20 g) were purchased from Da-Mool science (Daejeon, Republic of Korea). The animals were housed in a laminar air-flow room maintained at a temperature of $22 \pm 1{ }^{\circ} \mathrm{C}$ and a reactive humidity level of $55 \pm 1 \%$ throughout the study. All animal experimental processes were approved by the Wonkwang University Institutional Animal Care and Use Committee (Confirmation No. WKU14-34).

\section{Preparation of ID}

Ixeris dentata was obtained from the Wonkwang Institute of Biomedical Engineering Research and authenticated by Professor S. J. Park, College of Korean Medicine, Wonkwang University. A voucher specimen (No. 0517-12) was deposited at the Herbarium of the College of Pharmacy, Wonkwang University. It was prepared by decocting a dried prescription of herbs with distilled water for $3 \mathrm{~h}$. The extract was filtered, lyophilized, and kept at $4{ }^{\circ} \mathrm{C}$. The samples were dissolved in distilled water and then filtered through a $0.22 \mu \mathrm{m}$ syringe filter. The yield of the dried extract from the starting materials was about $7.8 \%$. A caffeic acid content analysis revealed a concentration of $4 \pm 0.00 \mathrm{mg} / \mathrm{g}(0.4 \pm 0.00 \%)$ [8].

\section{DNFB-induced dermatitis}

Experiments were performed according to a previously described method [28]. The dorsal skin of BALB/c mice $(n=7)$ was shaved by depilatory equipment before the 
experiment. The mice were sensitized with $100 \mu \mathrm{l}$ of $0.15 \%$ DNFB in an acetone olive oil (3: 1) or a vehicle applied to the dorsal skin twice each week for six weeks. ID $(1 \mathrm{mg} / \mathrm{kg})$ was orally administrated six weeks during the experiment.

\section{Histological analysis}

Dermatitis skins samples were excised from the mice $24 \mathrm{~h}$ after the final DNFB application and fixed with $10 \%$ formaldehyde, embedded in paraffin wax, routinely processed and then sectioned into $4-\mu \mathrm{m}$-thick slices. The skin sections were then stained with hematoxylin and eosin and examined by light microscopy for the presence of edema and for inflammatory cell accumulation.

\section{Enzyme-linked immunosorbent assay (ELISA)}

96-well plates were coated with capture antibodies overnight at $4{ }^{\circ} \mathrm{C}$. After washing with PBST, samples and cytokine standards were added and incubated at $37{ }^{\circ} \mathrm{C}$ for $2 \mathrm{~h}$. The plates were washed and biotinylated antibodies were added. The samples were then left for $2 \mathrm{~h}$. After washing, the plates were incubated with AP for $30 \mathrm{~min}$ in an incubator set to a temperature of $37^{\circ} \mathrm{C}$. Finally, TBS substrate solution was added and color development was measured by a microplate reader at $405 \mathrm{~nm}$.

\section{Preparation of total cell lysates and nuclear extracts and western blot analysis}

Stimulated cells were rinsed with ice-cold PBS and lysed using lysis buffer (iNtRon Biotech, Seoul, Republic of Korea) for $1 \mathrm{~h}$. Total cell lysates were centrifuged for $10 \mathrm{~min}$ at $4{ }^{\circ} \mathrm{C}$, after which the supernatants were obtained. Nuclear extracts were prepared using NE-PER Nuclear and Cytoplasmic Extraction Reagents (Pierce Thermo Scientific, Rockford, USA). After bicinchoninic acid (BCA) protein quantification, the supernatant was mixed with a $2 \times$ sample buffer, boiled for $5 \mathrm{~min}$, separated by $10 \%$ SDSpolyacrylamide gel electrophoresis, and then transferred to nitrocellulose membranes. The membranes were blocked with $10 \%$ skim milk for $1 \mathrm{~h}$ and $30 \mathrm{~min}$ and incubated for $3 \mathrm{~h}$ with primary antibodies. They were then incubated with secondary antibodies for $45 \mathrm{~min}$. Protein bands were detected using an ECL solution.

\section{Anaphylactic shock}

The mice $(\mathrm{n}=5)$ were administrated intraperitoneal injections of compound 48/80 (8 mg/kg). Control mice received a vehicle (PBS) and ID (0.01 - $1 \mathrm{~g} / \mathrm{kg})$ was orally administrated $1 \mathrm{~h}$ prior to the injection of compound $48 / 80$. Mortality was monitored for $1 \mathrm{~h}$ after the induction of anaphylactic shock.

\section{Cell culture}

Human immortalized keratinocytes (HaCaT cells) in RPMI 1640 supplemented with 10 \% FBS, 100 units/ml of penicillin, and $100 \mu \mathrm{g} / \mathrm{ml}$ of streptomycin were cultured in a humidified atmosphere of $5 \% \mathrm{CO}_{2} / 95 \%$ air at $37{ }^{\circ} \mathrm{C}$. The human mast cell line (HMC-1) were cultured in IMDM supplemented with 10 \% FBS, 100 units/ $\mathrm{ml}$ of penicillin, and $100 \mu \mathrm{g} / \mathrm{ml}$ of streptomycin in a humidified atmosphere of $5 \% \mathrm{CO}_{2} / 95 \%$ air at $37{ }^{\circ} \mathrm{C}$.

\section{Cell viability}

An MTT assay was performed to investigate the cell toxicity of ID and caffeic acid. MTT solution $(500 \mu \mathrm{g} / \mathrm{ml})$ was added, followed by incubation at $37^{\circ} \mathrm{C}$ for $4 \mathrm{~h}$. The crystallized formazan was dissolved in DMSO and the absorbance was measured at $540 \mathrm{~nm}$ by a microplate reader.

Reverse-transcriptase polymerase chain reaction (RT-PCR) Total RNA was isolated from $\mathrm{HaCaT}$ cells according to the manufacturer's specifications using an easy-BLUE RNA extraction kit (INtRON Biotech., Seoul, Republic of Korea). Total RNA and oligo(dT) $)_{15}$ were heated to $75{ }^{\circ} \mathrm{C}$ for $5 \mathrm{~min}$ and then placed on ice for at least 1 min. Each sample was reverse-transcribed to cDNA for $60 \mathrm{~min}$ at $42{ }^{\circ} \mathrm{C}$ using a cDNA synthesis kit. RT-PCR was performed with $1 \mu \mathrm{l}$ of a cDNA mixture with a final volume of $20 \mu \mathrm{l}$ with $10 \mathrm{pM}$ of cytokine primers, iMAX $^{\mathrm{TM}}$ II DNA Polymerase $(5 \mathrm{U} / \mu \mathrm{l})$, a $10 \times$ PCR buffer (300 mM Tris-HCl (pH 9.0); 300 mM salts containing $\mathrm{K}^{+}$ and $\mathrm{NH}_{4}^{+}$, with $\left.20 \mathrm{mM} \mathrm{Mg}{ }^{2+}\right)$, a dNTP mixture $(2.5 \mathrm{mM} /$ each), DEPC (diethylpyrocarbonate)-treated water. Amplification was conducted for 35 cycles, as follows: denaturation at $94{ }^{\circ} \mathrm{C}$ for $30 \mathrm{~s}$, annealing at $60{ }^{\circ} \mathrm{C}$ for $30 \mathrm{~s}$, and extension at $72{ }^{\circ} \mathrm{C}$ for $45 \mathrm{~s}$. Products were separated by electrophoresis on a $1.5 \%$ agarose gel and visualized by staining with ethidium bromide. The gels were certificated using a CN-TFX device (Vilber Lourmat, Marne-la-Vallée, France). The primer sequences are shown in Table 1.

\section{Statistical analysis}

The results are shown as a summary of the data from three experiments and are presented as the mean \pm SD. A statistical evaluation of the results was performed by the Student's $t$-test. For all experiments, $p<0.05$ was considered to be significant.

\section{Results}

Effect of ID on DNFB-induced dermatitis and serum IgE and IL-1 $\beta$ levels

The cutaneous application of DNFB was repeated to induce $\mathrm{AD}$-like skin lesion in BALB/c mice. As shown in Fig. 1a, AD-like skin lesions were recovered in the group administrated ID as compared to the DNFB-treated group 
Table 1 Sequences of the RT-PCR primers

\begin{tabular}{lll}
\hline Genes & Forward $\left(5^{\prime}-3^{\prime}\right)$ & Reverse $\left(5^{\prime}-3^{\prime}\right)$ \\
\hline IL-8 & GTCCTTGTCCACTGTGCCT & GCTTCCACATGTCCTCACAA \\
TARC & ACTGCTCCAGGGATGCCATCGTTIT & ACAAGGGGATGGGATCTCCCTCACTG \\
MDC & AGGACAGAGCATGGCTCGCCTACAGA & TAATGGCAGGGAGGTAGGGCTCCTGA \\
ICAM-1 & CACCCTAGAGCCAAGGTGAC & CATTGGAGTCTGCTGGGAAT \\
MMP-9 & CACTGTCCACCCCTCAGAGC & GCCACTTGTCGGCGATAAGG \\
$\beta$-actin & GGACTTCGAGCAAGAGATGG & AGCACTGTGTGGCGTACAG \\
\hline
\end{tabular}

(control). The dermatitis skins were stained with hematoxylin and eosin (H\&E) and evaluated by light microscopy. Marked accumulation of immune cells was observed in the control group, whereas the ID treatment inhibited hyperplasia (Fig. 1b). To evaluate the effects of ID on the inflammatory mediator production, blood samples were collected and analyzed using the ELISA method. Serum IgE and IL-1 $\beta$ levels were reduced by ID administration $(0.4213 \pm 0.02407$ and $0.1956 \pm 0.04152 \mathrm{ng} / \mathrm{ml})$ compared to the control group $(0.6677 \pm 0.02048$ and $0.2633 \pm 0.00392 \mathrm{ng} / \mathrm{ml}$ ) (Fig. $1 \mathrm{c}$ and d). These results indicated that the ID administration reduced dermal hyperplasia through the inhibition of inflammatory cell infiltration and inflammatory mediator production.

\section{Effect of ID on the phosphorylation of MAPKs and} transcription factors in DNFB-induced skin lesions

The activation of MAPKs induces the production of proinflammatory cytokines and is highly activated in allergic reactions, including dermatitis [25]. Therefore, we evaluated the effect of ID on the phosphorylation of MAPKs. An ID treatment suppressed the phosphorylation of ERK, JNK, and p38 in dorsal skin compared to the control group (Fig. 2a). The relative expression levels of the MAPKs are represented in Fig. $2 b$. Because NF- $k B$ is a pivotal transcription factor of inflammatory and immune reactions [22], the effect of ID on the activation of NF$\kappa \mathrm{B}$ was investigated. As shown in Fig. 2c, ID inhibited the phosphorylation of $I \kappa B \alpha$ and $N F-\kappa B$ translocation into the nucleus. The relative expression levels of transcription factors are represented in Fig. 2d. These results suggest that ID inhibits the activation of MAPKs and $\mathrm{NF}-\mathrm{kB}$ in AD-like skin lesions.

\section{Effect of ID on compound 48/80-induced anaphylactic shock}

The inhibitory effect of ID on anaphylactic shock produced by compound 48/80 was evaluated using BALB/c

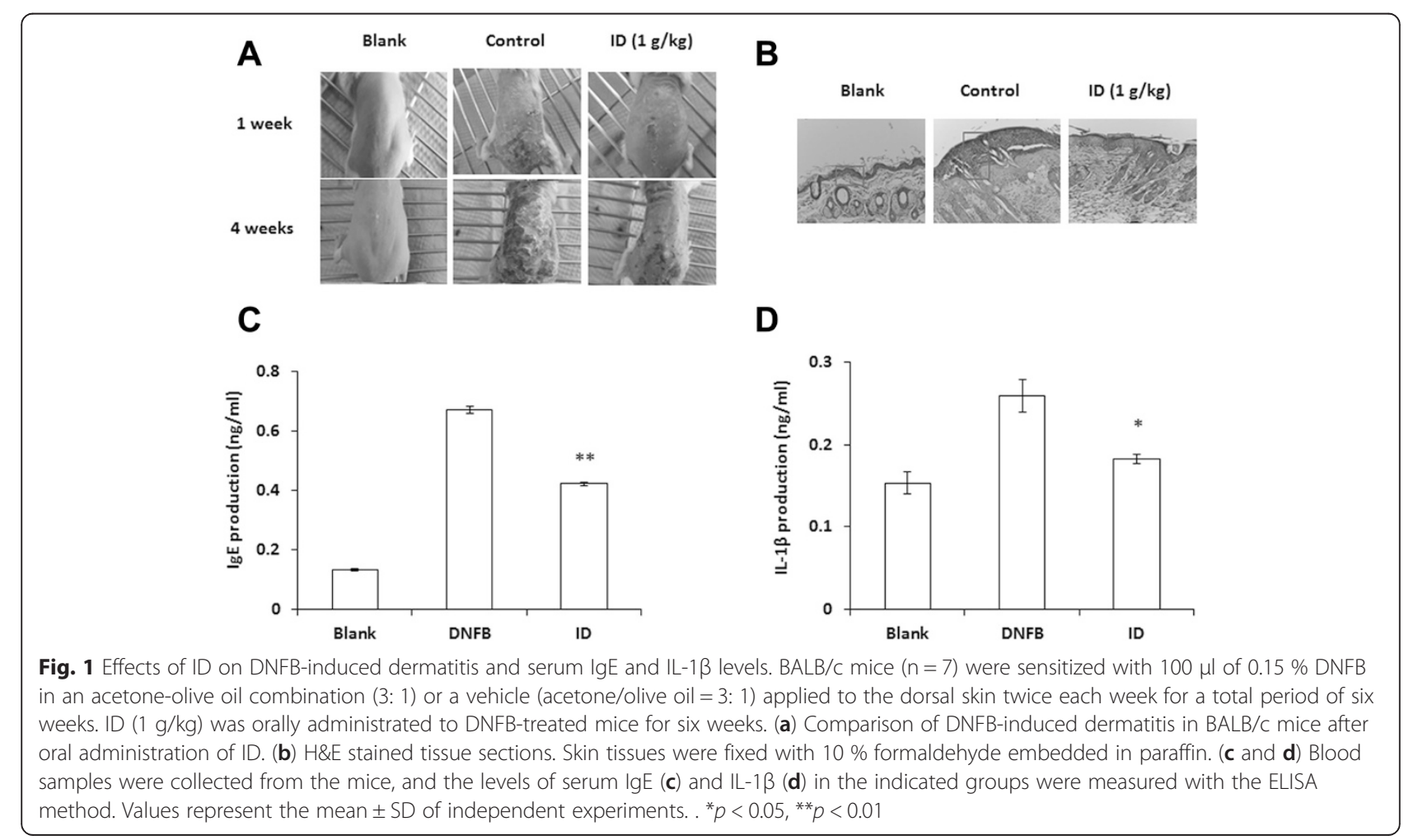


A

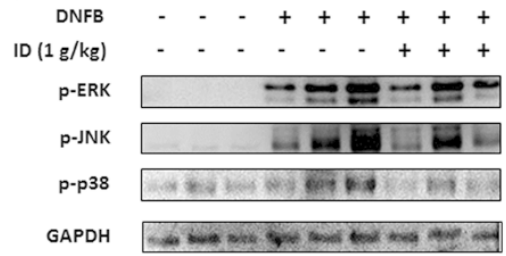

C

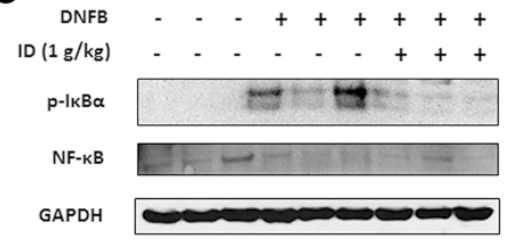

B

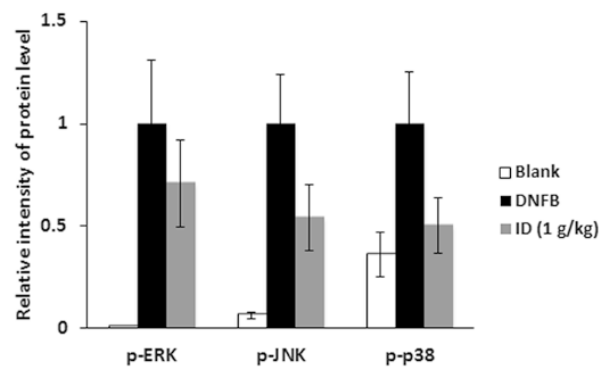

D

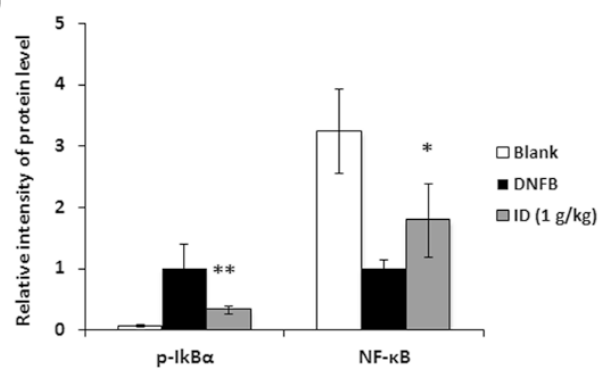

Fig. 2 Effects of ID on activation of MAPKs and NF-KB in skin lesions. Protein was isolated from normal or DNFB-induced dermatitis dorsal skin. (a) Phosphorylation levels of ERK, JNK, and p38 was assayed by western blot analysis. (b) Relative levels of p-ERK, p-JNK, and p-p38 were calculated using an image analyzer. Values represent the mean \pm SD of independent experiments. (c) The phosphorylation of IkBa and the protein expressions of NF-KB were assayed by western blot analysis. (d) The relative levels of $\mathrm{p}-\mathrm{I} \mathrm{kB}$ a and NF-KB were calculated using an image analyzer. Values represent the mean \pm SD of independent experiments. ${ }^{*} p<0.05,{ }^{* *} p<0.01$

mice. An oral administration of ID (0.01 - $1 \mathrm{~g} / \mathrm{kg})$ reduced the mortality rate induced by compound 48/80 in a dose-dependent manner (Table 2).

\section{Effects of ID and caffeic acid on the expression of chemokines in HaCaT cells}

Epidermal keratinocytes play multiple roles in the immune reactions associated with allergic contact dermatitis and atopic dermatitis skin diseases [12]. Therefore, the effect of ID on the degree of cell viability was first examined using an MTT assay. As shown in Fig. 3a, treatment with $0.01-1 \mathrm{mg} / \mathrm{ml}$ ID did not show cytotoxicity in $\mathrm{HaCaT}$ cells. To determine whether ID inhibits

Table 2 Effect of ID on the compound 48/80-induced systemic anaphylactic reaction

\begin{tabular}{lll}
\hline $\mathrm{ID}(\mathrm{g} / \mathrm{kg})^{\mathrm{a}}$ & Compound $48 / 80(8 \mathrm{mg} / \mathrm{kg})^{\mathrm{b}}$ & ${\text { Mortality }(\%)^{c}}^{c}$ \\
\hline None (saline) & + & 100 \\
0.01 & + & 80 \\
0.1 & + & 73.3 \\
1 & + & 46.6 \\
1 & - & 0
\end{tabular}

aThe groups of mice $(n=5)$ were orally administrated with saline or ID given at various doses $1 \mathrm{~h}$ before the compound 48/80 injection

${ }^{\mathrm{b}}$ The compound $48 / 80$ solution was intraperitoneally injected to the groups of mice

${ }^{c}$ Mortality (\%) was presented as the 'Number of dead mice $\times 100 /$ Total number of experimental mice'. This result was represented by average results from three independent experiments the production of TNF- $\alpha / \mathrm{IFN}-\gamma$-induced chemokines, we carried out a RT-PCR analysis and ELISA tests. The expression levels of chemokines (IL-8, TARC, and MDC), ICAM-1, and MMP-9 were suppressed by the ID treatment (Fig. 3c). The relative mRNA expression levels are represented in Fig. 3e. In previous research, we found through an HPLC analysis that caffeic acid was a major compound of ID [8]. Thus, we investigated the effect of caffeic acid on the production of cytokines and chemokines in $\mathrm{HaCaT}$ cells. Concentrations of caffeic acid were determined using MTT assay (Fig. 3b). Caffeic acid decreased chemokines including IL-8, TARC and MDC as well as ICAM-1 and MMP-9 expressions were decreased by the caffeic acid treatment (Fig. 3d). The relative mRNA expression levels are represented in Fig. 3f.

\section{Effects of ID on the production of proinflammatory cytokines and the activation of MAPKs in HMC-1 cells}

Mast cells play a role in allergic reactions through the release of a number of mediators and cytokines [29]. We determined whether ID regulates the levels of proinflammatory cytokines in HMC-1 cells. First, we checked the cytotoxicity of ID on HMC-1 cells using an MTT assay (Fig. 4a). In the activated $\mathrm{HMC}-1$ cells, ID significantly suppressed the production of TNF- $\alpha$ and IL-8, but not IL-6 (Fig. 4b-d). Moreover, we investigated the regulatory effects of ID on the activation of MAPKs. ID 
A

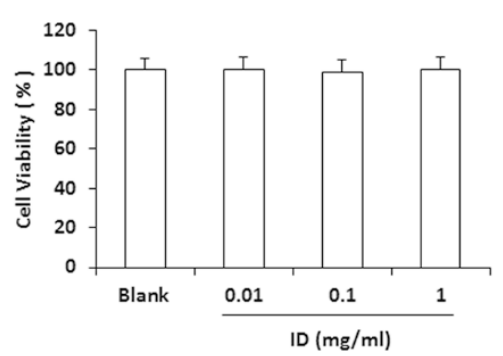

C

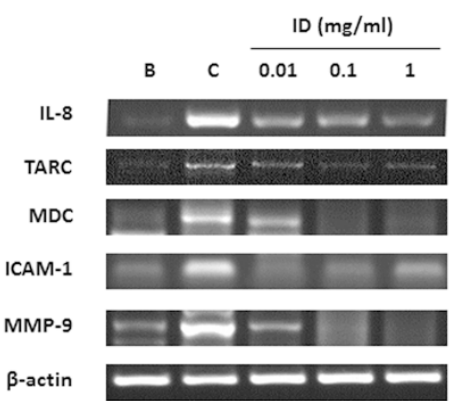

E

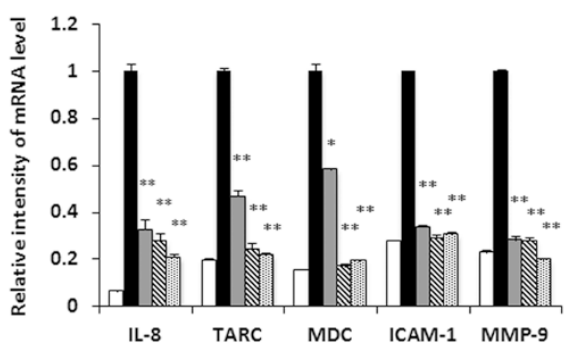

$\square$ Blank $\square$ Control $\square$ ID $0.01 \mathbb{Q} I D 0.1 \quad$ DID $1(\mathrm{mg} / \mathrm{ml})$
B

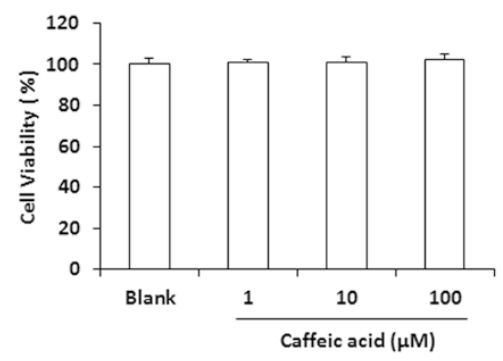

D

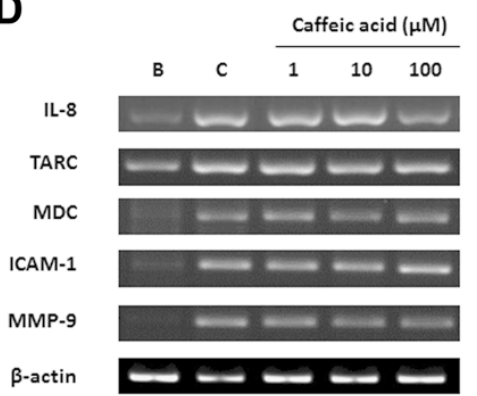

F

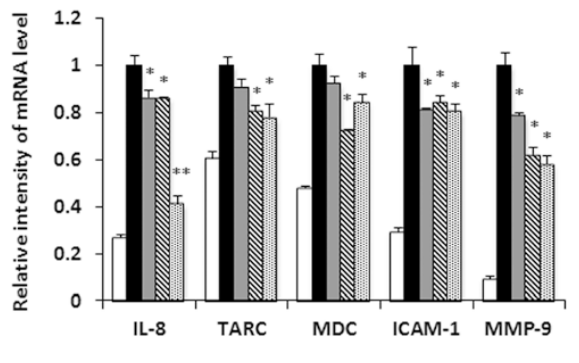

Fig. 3 Effects of ID and caffeic acid on the expression levels of inflammatory mediators in HaCaT cells. (a and b) HaCaT cells ( $2 \times 10^{5}$ cells/well) were treated with ID $(0.01-1 \mathrm{mg} / \mathrm{ml})$ or caffeic acid $(1-100 \mu \mathrm{M})$ for $12 \mathrm{~h}$ and the degree of cell viability was analyzed by an MTT assay. (c and $\mathbf{d})$ HaCaT cells $\left(2 \times 10^{5}\right.$ cells/well) were pre-treated with ID or caffeic acid for 30 min and were stimulated with TNF-a/IFN- $\gamma$ for 18 h. The levels of cytokine were assayed by a RT-PCR analysis. (e and $\mathbf{f}$ ) Relative levels of IL-8, TARC, MDC, ICAM-1, and MMP-9 were calculated using an image analyzer. Values represent the mean \pm SD of three independent experiments. CA, caffeic acid. ${ }^{*} p<0.05,{ }^{* *} p<0.01$

decreased the PMA + A23187-induced phosphorylation of p38 and ERK while the results for JNK showed no changes (Fig. 4e). ID also inhibited the phosphorylation of $\mathrm{I} \kappa \mathrm{B} \alpha$ and the nuclear localization of NF- $\mathrm{B}$ (Fig. 4f). These results suggest that ID suppresses the activation of NF- $\mathrm{kB}$ via 338 and ERK phosphorylation.

\section{Effects of caffeic acid on the production of} proinflammatory cytokines and the activation of MAPKs in $\mathrm{HMC}-1$ cells

To investigate whether caffeic acid inhibits the production of cytokines, the TNF- $\alpha$, IL- 8 , and IL- 6 levels were measured by the ELISA method. The concentration of caffeic acid in HMC-1 cells was determined by an MTT assay (Fig. 5a). Caffeic acid significantly reduced the levels of TNF- $\alpha$ and IL-8, but not IL-6 (Fig. 5b-d). We examined the regulatory effects of caffeic acid on the phosphorylation of MAPKs (p38, ERK, and JNK). Caffeic acid decreased the PMA + A23187-induced phosphorylation of p38, while the results for ERK and JNK showed no changes (Fig. 5e). Additionally, caffeic acid inhibited the degradation of IкB $\alpha$ and the nuclear localization of NF- $\mathrm{B}$ (Fig. 5f). These results suggest that caffeic acid suppresses the activation of NF- $\mathrm{BB}$ via the inhibition of p38 phosphorylation.

\section{Discussion}

$\mathrm{AD}$ is a chronic inflammatory skin disease associated with cutaneous hyperreactivity to environmental triggers and skin inflammatory responses driven by cytokines expression. Furthermore, the incidence of $\mathrm{AD}$ has continued to increase over the past several decades [17]. Common 
A

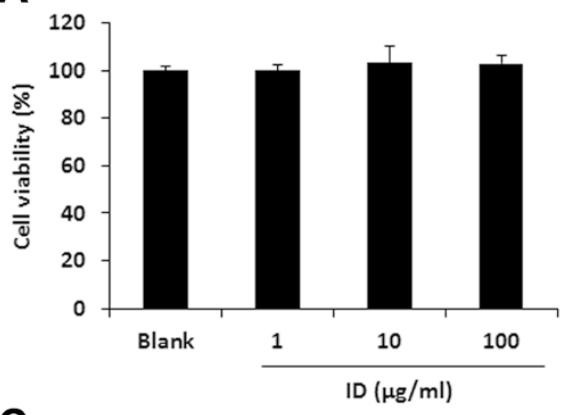

C

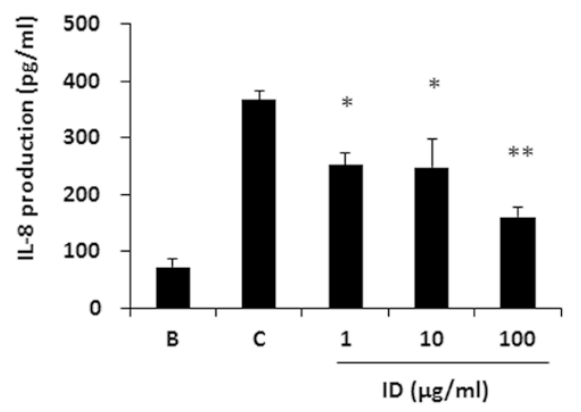

E

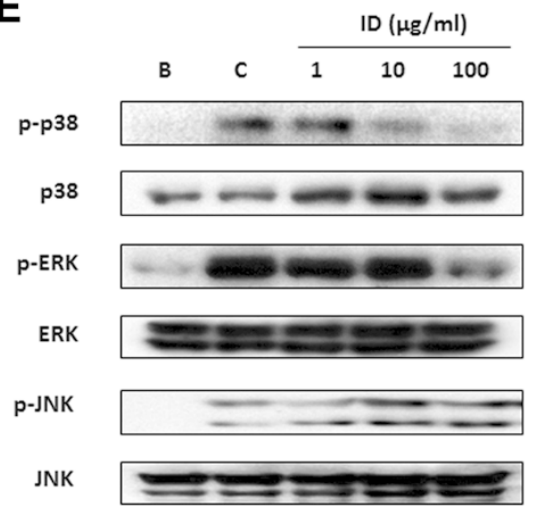

B

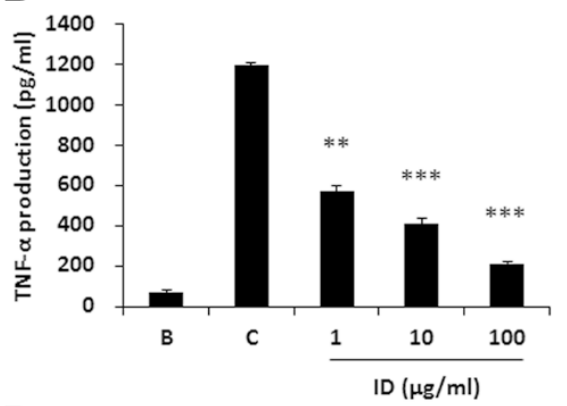

D

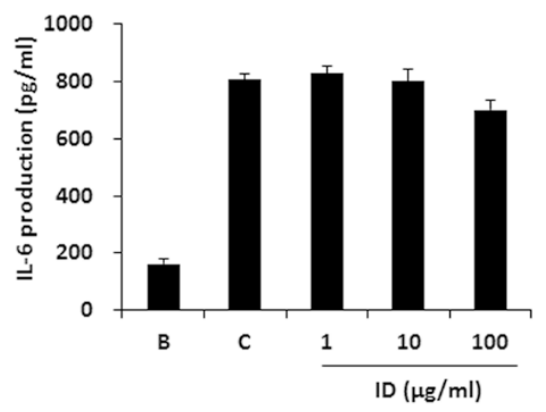

$\mathbf{F}$

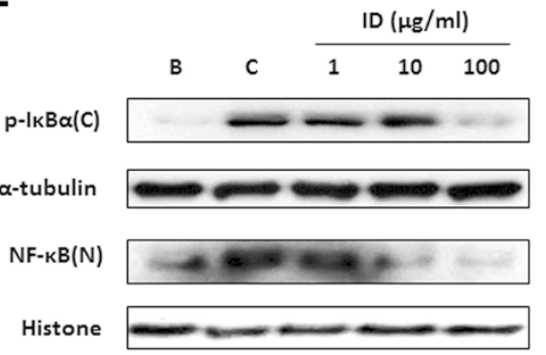

Fig. 4 Effects of ID on the production of proinflammatory cytokines and the activation of MAPKs and NF-KB in HMC-1 cells. (a) HMC-1 cells $\left(1 \times 10^{4}\right.$ cells/well) were treated with ID $(0.01-1 \mathrm{mg} / \mathrm{ml})$ for $24 \mathrm{~h}$ and the cell viability was analyzed with MTT assays. (b-d) The production levels of TNF-a (B), IL-8 (c), and IL-6 (d) were measured using the ELISA method. HMC-1 cells $\left(2 \times 10^{5}\right.$ cells/well) were pre-treated with ID for $1 \mathrm{~h}$ and were stimulated with PMA $(50 \mathrm{nM})+\mathrm{A} 23187(1 \mu \mathrm{M})$ for $8 \mathrm{~h}$. Values represent the mean \pm SD of three independent experiments. ${ }^{*} p<0.05$, ** $p<0.01,{ }^{* *} p<0.001$. (e and $\mathbf{f}$ ) Phosphorylation of $\mathrm{p} 38$, ERK and JNK (e) and the phosphorylation of IKBa and translocation of NF-KB (f) were assayed by western blot analysis. HMC-1 cells $\left(1 \times 10^{6}\right.$ cells/well) were incubated with various concentrations of ID and then stimulated with PMA $(50 \mathrm{nM})+\mathrm{A} 23187(1 \mu \mathrm{M})$ for $30 \mathrm{~min}(\mathbf{e})$ or $2 \mathrm{~h}$ (f). C, cytosol extracts; N, nuclear extracts

treatments for $\mathrm{AD}$ are steroid therapy and immunosuppressive drugs, but these show side-effects, especially with continuous application [30]. Therefore, researchers have attempted to find a new drug in complementary and alternative medicines, such as herbal medicines [31, 32]. In this study, we demonstrated the regulatory effect of ID on allergic reactions in vivo and in vitro.

Haptens such as DNFB are used to induce a model of murine-contact hypersensitivity $(\mathrm{MCH})$. It has been reported that $\mathrm{MCH}$ can generate $\mathrm{AD}$-like skin lesions and immune responses with Th1-and/or Th2-type inflammation under certain conditions [33]. Dermatitis is characterized as a potent form of skin inflammation associated with an elevated level of IgE and the activation of IL-1 $\beta$ [34-36]. In this study, we mainly focused on the regulation of ID on proinflammatory cytokines but not Th2 cytokines, since it has been reported that the inhibitory effect of ID on DSS-induced colitis is due to the reduction of proinflammatory cytokines including TNF- $\alpha$ and IL- 6 in previous study [8]. Therefore, we repeated the application of DNFB to induce $\mathrm{AD}$-like lesions in $\mathrm{BALB} / \mathrm{c}$ mice and investigated an 
A

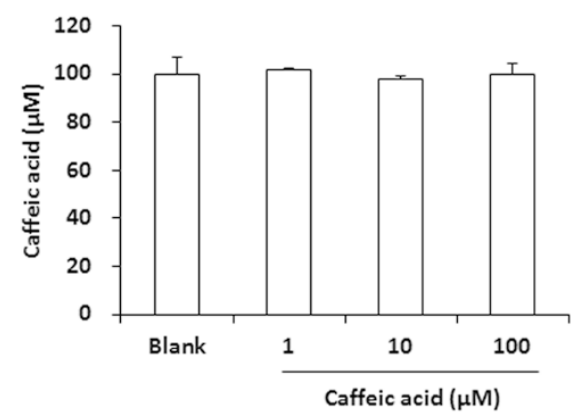

C

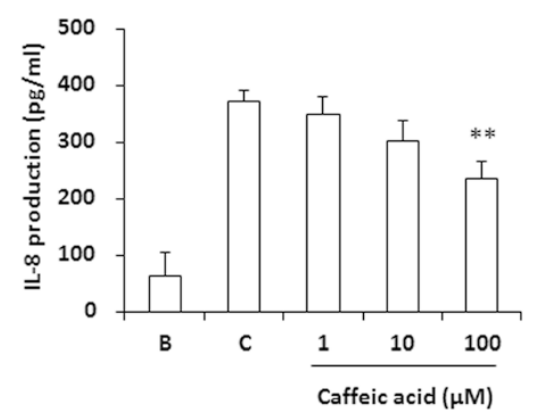

E

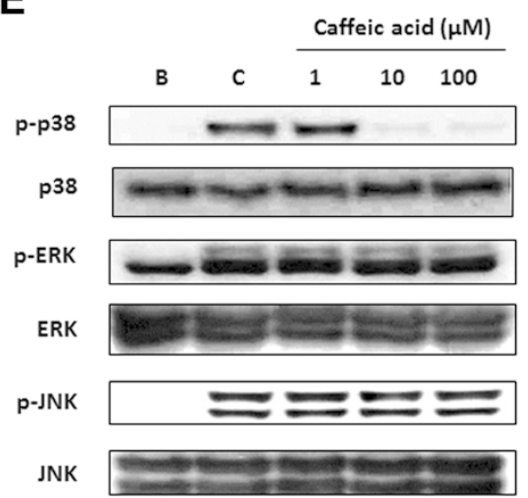

B

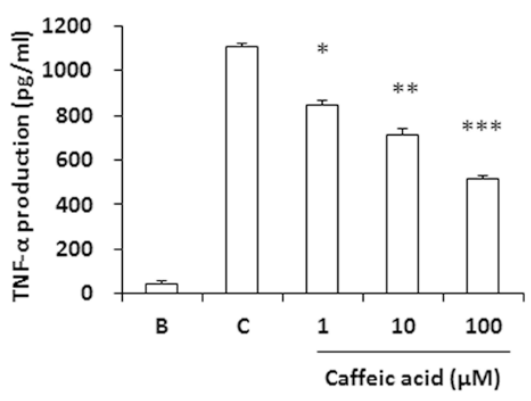

D

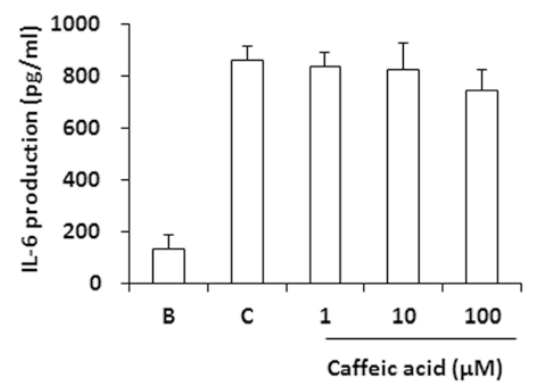

$\mathbf{F}$

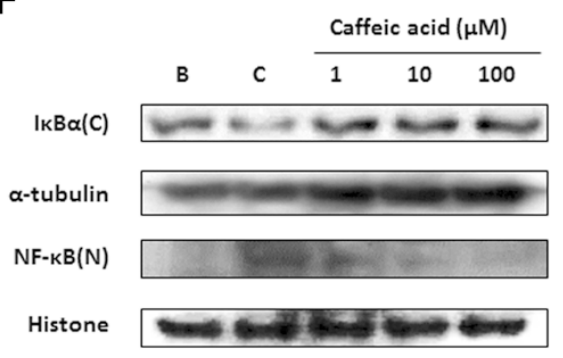

Fig. 5 Effects of caffeic acid on the production of proinflammatory cytokines and the activation of MAPKs and NF-KB in HMC-1 cells. (a) HMC-1 cells $\left(1 \times 10^{4}\right.$ cells/well) were treated with caffeic acid (1-100 $\left.\mu \mathrm{M}\right)$ for $24 \mathrm{~h}$ and the degree of cell viability was analyzed with MTT assays. (b-d) The production levels of TNF- $a(\mathbf{b}), I L-8(\mathbf{c})$, and IL-6 $(\mathbf{d})$ were measured using the ELISA method. HMC-1 cells $\left(2 \times 10^{5}\right.$ cells/well) were pre-treated with caffeic acid for $1 \mathrm{~h}$ and were stimulated with PMA $(50 \mathrm{nM})+\mathrm{A} 23187(1 \mu \mathrm{M})$ for $8 \mathrm{~h}$. Values represent the mean \pm SD of three independent experiments. ${ }^{*} p<0.05,{ }^{* *} p<0.01,{ }^{* * *} p<0.001$. (e and $\mathbf{f}$ ) Phosphorylation of $\mathrm{p} 38$, ERK and JNK (e) and the degradation of IKBa and translocation of NF-KB (f) were assayed by western blot analysis. HMC-1 cells $\left(1 \times 10^{6}\right.$ cells/well) were incubated with various concentrations of caffeic acid and then stimulated with

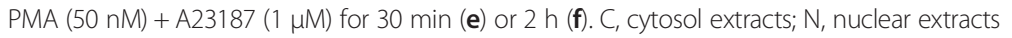

effect of ID treatment. ID significantly reduced DNFBinduced dermatitis and decreased the serum levels of IgE and the IL- $1 \beta$ via the inhibition of $\mathrm{p} 38$, ERK, and JNK phosphorylation as well as the activation of NF- $\mathrm{kB}$ in AD-like skin lesions (Fig. 1 and 2). Compound 48/ 80 , one of the most potent secretagogues, increases the permeability of the lipid bilayer membrane by causing a perturbation in the membrane upon mast cell degranulation [37]. ID administration also inhibited compound 48/80-induced anaphylactic shock in dose-dependent manner (Table 2). These results indicate that ID has a potent effect on anti-allergic responses in mice model.

$\mathrm{HaCaT}$ cells, a spontaneously transformed human keratinocyte cell line, are commonly used in pharmacological studies of skin diseases such as dermatitis, as it produces proinflammatory cytokines and chemokines upon various types of stimulation. $\mathrm{HaCaT}$ cells develop skin-associated lymphoid tissue by increasing the levels of surface antigens and interacting with other immunocytes [38]. TARC and MDC, typical Th2 chemokines, 
are both induced in $\mathrm{HaCaT}$ cells upon stimulation with IFN- $\gamma$ and TNF- $\alpha$ [39]. As the chemokine, IL-8 plays a role in the activation of inflammatory effector cells such as neutrophils, T-lymphocytes, and eosinophils [40]. In this study, ID inhibited the mRNA expression of chemokines (IL-8, TARC, and MDC), and the adhesion molecule (ICAM-1), and MMP-9. Caffeic acid also reduced the expressions of IL- 8 and TARC in TNF- $\alpha /$ IFN- $\gamma$-stimulated HaCaT cells (Fig. 3).

Mast cells play an important role in both adaptive and innate immunity and show increases in immunological skin diseases, including dermatitis [41]. The HMC-1 cell line was established from leukemia patients; it expresses characteristic markers for mast cells [42]. In response to different types of stimulation, mast cells release an array of cytokines, especially TNF- $\alpha$, IL- 6 , and IL- 8 , with the potential to cause inflammation [18]. Therefore, the inhibition of cytokine secretion can be a useful therapeutic strategy for allergic inflammatory diseases such as AD. In this study, we demonstrated that ID and caffeic acid decreased the production of TNF- $\alpha$ and IL- 8 in PMA + A23187-stimulated HMC-1 cells (Fig. 4 and 5). The expressions of proinflammatory cytokines such as TNF- $\alpha$, IL-6, and IL-8 are associated with the activation of MAPKs and transcription factor NF-кB [25, 26]. To elucidate the mechanisms of the ID-mediated inhibition of proinflammatory cytokine production, we examined the regulatory effect of ID on the intracellular signaling molecules involved in the PMA + A23187-induced signaling pathways. ID decreases the nuclear translocation of NF$\mathrm{KB}$ via the p38 and ERK, whereas caffeic acid regulates the phosphorylation of p38 but not ERK or JNK (Fig. 4 and 5). These results demonstrate that ID and caffeic acid suppress the production of proinflammatory cytokines through the phosphorylation of MAPKs and the activation of the NF-kB pathway. In contrast, we were unable to find the inhibitory effect of ID and caffeic acid on IL-6 production. Other studies demonstrated that IL-6 production is regulated by JNK activation in renal epithelial cells and PMA-stimulated Jurkat T cells [43, 44]. Since the drugs might not affect JNK activation, consequently both drugs did not decrease the IL-6 production.

In a previous study, we found that ID contained approximately $4 \mathrm{mg} / \mathrm{g}$ of caffeic acid (3,4-dihydroxy cinamic acid) [8]. Approximately 20 types of sesquiterpene and other compounds have been isolated from ID. It has been reported that its main compounds are luteolin, luteolin 7O-glucuronide, caffeic acid, chlorogenic acid, and guaiane sesquiterpene lactones [45, 46]. Among these main compounds, inhibitory effects of luteolin, chlorogenic acid, and tectroside on allergic inflammation had already been reported [9, 47-49]. Thus, we focused on ID and caffeic acid and demonstrated both drugs' anti-allergic inflammatory effect on $\mathrm{HaCaT}$ and $\mathrm{HMC}-1$ cells. Caffeic acid was effective for reducing inflammatory responses with regard to TPA-induced ear thickness, and TPA/calcium ionophore or TNF- $\alpha$-stimulated $\mathrm{HaCaT}$ cells $[50,51]$. Therefore, caffeic acid may be partly responsible for the anti-allergic effect of ID. Indeed, we showed in present study that caffeic acid reduced the expressions of IL-8 and TARC as well as p38/NF- $\mathrm{kB}$ pathway in TNF- $\alpha /$ IFN- $\gamma$-stimulated $\mathrm{HaCaT}$ cells and $\mathrm{HMC}-1$ cells.

In this study, ID decreased the production of proinflammatory cytokines including TNF- $\alpha$ and IL-8 in mast cells and inhibited TNF- $\alpha / \mathrm{IFN}-\gamma$-induced expression of chemokines such as IL-8, TARC and MDC in HaCaT cells. We showed that ID also reduced the expression of MMP-9, which is induced by histamine in keratinocyte [52]. Yi et al. [10] reported that ID inhibited the histamine release in mast cells. Therefore we suggest that reduced MMP-9 expression in keratinocytes by ID may be due to inhibition of ID on histamine release. These responses might also be occurred via blockage of the p38 and ERK/NF- $\mathrm{kB}$ pathway in mast cells and keratinocytes by ID treatment. In addition, MAPKs/NF- $\kappa B$ activation was inhibited by ID administration in AD-like skin lesion mice model. Consequently, ID water extract can improve the allergic inflammatory diseases through inhibition of proinflammatory cytokines, chemokines, and MMP-9 by regulation of MAPKs/NF-KB pathway in mast cells and keratinocytes.

\section{Conclusions}

Our data suggest that ID can be used in the treatment of allergic skin diseases, including AD. ID showed antiinflammatory and anti-allergic activities by suppressing skin dermatitis in DNFB-sensitized mice and compound 48/80-induced systemic anaphylaxis through the inhibition of serum IgE and IL- $1 \beta$ release. In addition, ID inhibited the TNF- $\alpha / \mathrm{IFN}-\gamma$-induced expression of chemokines (IL-8, TARC, and MDC), ICAM-1, and MMP-9 in keratinocytes. Moreover, ID reduced proinflammatory cytokines (TNF- $\alpha$ and IL-8) via the blockage of p38/ERK phosphorylation and NF- $\mathrm{kB}$ activation in mast cells. These results lend insight into the pharmacological actions of ID as a potential therapy for allergic inflammatory diseases such as dermatitis.

\section{Competing interests}

The authors declare that there are no conflicts of interest.

\section{Author's contributions}

Y-D Jeon, J-Y Kee and D-S Kim performed the in vitro experiments and analysed the data. Y-D Jeon and Y-H Han performed the in vivo mouse model experiment and analysed the data. S-H Kim and S-J Kim provided technical and material support. Y-D Jeon and J-Y Kee collected the data, undertook the statistical analyses, and wrote the manuscript. J-Y Um and S-H Hong designed and supervised the study, including editing of the manuscript. All authors contributed to and have approved the final manuscript. 


\section{Acknowledgements}

This work was supported by the National Research Foundation of Korea (NRF) grant funded by the Korea government (MSIP) (No. 2012M2B2B1055244, No. 2011-0030130, and No. 2011-0006220).

\section{Author details}

${ }^{1}$ Department of Oriental Pharmacy, College of Pharmacy, Wonkwang-Oriental Medicines Research Institute, Wonkwang University, Jeonbuk 570-749, Republic of Korea. ${ }^{2}$ Department of Oriental Medicine Resources, College of Environmental \& Bioresources Sciences, Chonbuk National University, Iksan, Republic of Korea. ${ }^{3}$ College of Korean Medicine, Institute of Korean Medicine, Kyung Hee University, 26 Kyungheedae-ro, Dongdaemun-gu, Seoul, Republic of Korea. ${ }^{4}$ Department of Cosmeceutical Science, Daegu Hanny University, Yugok-dong, Kyungsan 712-715, Republic of Korea.

\section{Received: 21 October 2014 Accepted: 29 May 2015} Published online: 24 June 2015

\section{References}

1. Leung DY, Bieber T. Atopic dermatitis. Lancet. 2003;361:151-60.

2. Leung DY, Boguniewicz M, Howell MD, Nomura I, Hamid QA. New insights into atopic dermatitis. J Clin Invest. 2004;113:651-7.

3. Bonness S, Bieber T. Molecular basis of atopic dermatitis. Curr Opin Allergy Clin Immunol. 2007;7:382-6.

4. Novak N. New insights into the mechanism and management of allergic diseases: atopic dermatitis. Allergy. 2009;64:265-75.

5. Ahn EM, Bang MH, Song MC, Park MH, Kim HY, Kwon BM, et al. Cytotoxic and ACAT-inhibitory sesquiterpene lactones from the root of Ixeris dentata forma albiflora. Arch Pharm Res. 2006;29:937-41.

6. Oh SH, Sung TH, Kim MR. Ixeris dentata extract maintains glutathione concentrations in mouse brain tissue under oxidative stress induced by kainic acid. J Med Food. 2003;6:353-8.

7. Lee HY, Lee GH, Kim HK, Kim SH, Kp P, Chae HJ, et al. Ixeris dentata-induced regulation of amylase synthesis and secretion in glucose-treated human salivary gland cells. Food Chem Toxicol. 2013;62:739-49.

8. Kim DS, Ko JH, Jeon YD, Han YH, Kim HJ, Poudel A, et al. Ixeris dentata NAKAI Reduces Clinical Score and HIF-1 Expression in Experimental Colitis in Mice. Evid Based Complement Alternat Med. 2013;2013:671281.

9. Kim SB, Kang OH, Joung DK, Mun SH, Seo YS, Cha MR, et al. Antiinflammatory effects of tectroside on UVB-induced HaCaT cells. Int J Mol Med. 2013;31:1471-6.

10. Yi JM, Hong SH, Lee HJ, Won JH, Kim JM, Jeong DM, et al. Ixeris dentata green sap inhibits both compound 48/80-induced aanaphylaxis-like response and lgEmediated anaphylactic response in murine model. Biol Pharm Bull. 2002;25:5-9.

11. Park EK, Sung JH, Trinh HT, Bae EA, Yun HK, Hong SS, et al. Lactic acid bacterial fermentation increases the antiallergic effects of Ixeris dentata. J Microbiol Biotechnol. 2008;18:308-13.

12. Albanesi C. Keratinocytes in allergic skin diseases. Curr Opin Allergy Clin Immunol. 2010;10:452-6.

13. Pastore S, Lulli D, Potapovich Al, Fidanza P, Kostyuk VA, Dellambra E, et al. Differential modulation of stress-inflammation responses by plant polyphenols in cultured normal human keratinocytes and immortalized HaCaT cells. J Dermatol Sci. 2011;63:104-14.

14. Albanesi C, Scarponi C, Cavani A, Federici M, Nasorri F, Girolomoni G. Interleukin-17 is produced by both Th1 and Th2 lymphocytes, and modulates interferon-gamma- and interleukin-4-induced activation of human keratinocytes. J Invest Dermatol. 2000;115:81-7.

15. Saeki H, Tamaki K. Thymus and activation regulated chemokine (TARC)/ CCL17 and skin diseases. J Dermatol Sci. 2006;43:75-84.

16. Hijnen D, De Bruin-Weller M, Oosting B, Lebre C, De Jong E, BruijnzeelKoomen $C$, et al. Serum thymus and activation-regulated chemokine (TARC) and cutaneous T cell- attracting chemokine (CTACK) levels in allergic diseases: TARC and CTACK are disease-specific markers for atopic dermatitis. J Allergy Clin Immunol. 2004;113:334-40.

17. Leung TF, Ma KC, Hon KL, Lam CW, Wan H, Li CY, et al. Serum concentration of macrophage-derived chemokine may be a useful inflammatory marker for assessing severity of atopic dermatitis in infants and young children. Pediatr Allergy Immunol. 2003;14:296-301.

18. Galli SJ, Kalesnikoff J, Grimbaldeston MA, Piliponsky AM, Williams CM, Tsai M. Mast cells as "tunable" effector and immunoregulatory cells: recent advances. Annu Rev Immunol. 2005;23:749-86.
19. Galli SJ, Tsai M. Mast cells in allergy and infection: versatile effector and regulatory cells in innate and adaptive immunity. Eur J Immunol. 2010;40:1843-51

20. Kawakami T, Ando T, Kimura M, Wilson BS, Kawakami Y. Mast cells in atopic dermatitis. Curr Opin Immunol. 2009;21:666-78.

21. Finco TS, Baldwin AS. Mechanistic aspects of NF-kappa B regulation: the emerging role of phosphorylation and proteolysis. Immunity. 1995;3:263-72.

22. Barnes PJ, Karin M. Nuclear factor-kappaB: a pivotal transcription factor in chronic inflammatory diseases. N Engl J Med. 1997;336:1066-71.

23. Barnes PJ. Pathophysiology of allergic inflammation. Immunol Rev. 2011;242:31-50.

24. Johnson GL, Lapadat R. Mitogen-activated protein kinase pathways mediated by ERK, JNK, and p38 protein kinases. Science. 2002;298:1911-2.

25. Hommes DW, Peppelenbosch MP, van Deventer SJ. Mitogen activated protein (MAP) kinase signal transduction pathways and novel anti-inflammatory targets. Gut. 2003;52:144-51.

26. May MJ, Ghosh S. Signal transduction through NF-kappa B. Immunol Today. 1998;19:80-8.

27. Arthur JS, Ley SC. Mitogen-activated protein kinases in innate immunity. Nat Rev Immunol. 2013;13:679-92.

28. Kim SJ, Kee JY, Choi IY, Kim MC, Kim DS, Jeon YD, et al. Insamhodo-tang, a traditional Korean medicine, regulates mast cell-mediated allergic inflammation in vivo and in vitro. J Ethnopharmacol. 2011;134:339-47.

29. Gould HJ, Sutton BJ, Beavil AJ, Beavil RL, McCloskey N, Coker HA, et al. The biology of IGE and the basis of allergic disease. Annu Rev Immunol. 2003;21:579-628.

30. Cohen DE, Heidary N. Treatment of irritant and allergic contact dermatitis. Dermatol Ther. 2004;17:334-40

31. Tan HY, Zhang AL, Chen D, Xue CC, Lenon GB. Chinese herbal medicine for atopic dermatitis: a systematic review. J Am Acad Dermatol. 2013;69:295-304.

32. Yamashita $\mathrm{H}$, Tanaka $\mathrm{H}$, Inagaki $\mathrm{N}$. Treatment of the chronic itch of atopic dermatitis using standard drugs and kampo medicines. Biol Pharm Bull. 2013;36:1253-7.

33. Honda T, Egawa G, Grabbe S, Kabashima K. Update of immune events in the murine contact hypersensitivity model: toward the understanding of allergic contact dermatitis. J Invest Dermatol. 2013;133:303-15.

34. Allam JP, Novak N. The pathophysiology of atopic eczema. Clin Exp Dermatol. 2006:31:89-93.

35. Liu FT, Goodarzi H, Chen HY. IgE, mast cells, and eosinophils in atopic dermatitis. Clin Rev Allergy Immunol. 2011:41:298-310.

36. Watanabe H, Gaide O, Pétrilli V, Martinon F, Contassot E, Roques S, et al. Activation of the IL-1 beta-processing inflammasome is involved in contact hypersensitivity. J Invest Dermatol. 2007;127:1956-63.

37. Tasaka K, Mio M, Okamoto M. Intracellular calcium release induced by histamine releasers and its inhibition by some antiallergic drugs. Ann Allergy. 1986;56:464-9.

38. Boukamp P, Petrussevska RT, Breitkreutz D, Hornung J, Markham A, Fusenig NE. Normal keratinization in a spontaneously immortalized aneuploid human keratinocyte cell line. J Cell Biol. 1988;106:761-71.

39. Horikawa T, Nakayama T, Hikita I, Yamada H, Fujisawa R, Bito T, et al. IFNgamma-inducible expression of thymus and activation-regulated chemokine/ CCL17 and macrophage-derived chemokine/CCL22 in epidermal keratinocytes and their roles in atopic dermatitis. Int Immunol. 2002;14:767-73.

40. Sebastiani S, Albanesi C, De PO, Puddu P, Cavani A, Girolomoni G. The role of chemokines in allergic contact dermatitis. Arch Dermatol Res. 2002;293:552-9.

41. Navi D, Saegusa J, Liu FT. Mast cells and immunological skin diseases. Clin Rev Allergy Immunol. 2007;33:144-55.

42. Hamann K, Grabbe J, Welker P, Haas N, Algermissen B, Czarnetzki BM. Phenotypic evaluation of cultured human mast and basophilic cells and of normal human skin mast cells. Arch Dermatol Res. 1994;286:380-5.

43. de Haij S, Bakker AC, van der Geest RN, Haegeman G, Vanden Berghe W, Aarbiou J, et al. NF-kappaB mediated IL-6 production by renal epithelial cells is regulated by c-jun NH2-terminal kinase. J Am Soc Nephrol. 2005;16:1603-11.

44. Khalaf H, Jass J, Olsson PE. Differential cytokine regulation by NF-kappaB and AP-1 in Jurkat T-cells. BMC Immunol. 2010;11:26.

45. Cha MR, Choi YH, Choi CW, Yoo DS, Kim YS, Choi SU, et al. New guaiane sesquiterpene lactones from Ixeris dentata. Planta Med. 2011;77:380-2.

46. Karki S, Park HJ, Nugroho A, Kim EJ, Jung HA, Choi JS. Quantification of major compounds from Ixeris dentata, Ixeris dentata Var. albiflora, and Ixeris sonchifolia and their comparative anti-inflammatory activity in lipopolysaccharide-stimulated RAW 264.7 cells. J Med Food. 2015;18:83-94. 
47. Kritas SK, Saggini A, Varvara G, Murmura G, Caraffa A, Antinolfi P, et al. Luteolin inhibits mast cell-mediated allergic inflammation. J Biol Regul Homeost Agents. 2013;27:955-9.

48. Kwon OS, Choi JS, Islam MN, Kim YS, Kim HP. Inhibition of 5-lipoxygenase and skin inflammation by the aerial parts of Artemisia capillaris and its constituents. Arch Pharm Res. 2011;34:1561-9.

49. Trinh HT, Bae EA, Hyun YJ, Jang YA, Yun HK, Hong SS, et al. Anti-allergic effects of fermented Ixeris sonchifolia and its constituent in mice. J Microbiol Biotechnol. 2010;20:217-23.

50. Zhang M, Zhou J, Wang L, Li B, Guo J, Guan X, et al. Caffeic acid reduces cutaneous tumor necrosis factor alpha (TNF-a), IL-6 and IL-1 $\beta$ levels and ameliorates skin edema in acute and chronic model of cutaneous inflammation in mice. Biol Pharm Bull. 2014:37:347-54.

51. Hossen MA, Inoue T, Shinmei Y, Minami K, Fujii Y, Kamei C. Caffeic acid inhibits compound 48/80-induced allergic symptoms in mice. Biol Pharm Bull. 2006;29:64-6.

52. Harvima IT. Induction of matrix metalloproteinase-9 in keratinocytes by histamine. J Invest Dermatol. 2008;128:2748-50.

\section{Submit your next manuscript to BioMed Central and take full advantage of:}

- Convenient online submission

- Thorough peer review

- No space constraints or color figure charges

- Immediate publication on acceptance

- Inclusion in PubMed, CAS, Scopus and Google Scholar

- Research which is freely available for redistribution 